\title{
SOIL PH AND ITS ROLE IN CYANOBACTERIAL ABUNDANCE AND DIVERSITY IN RICE FIELD SOILS
}

\author{
S. NAYAK - R. PRASANNA* \\ Centre for Conservation and Utilization of Blue-Green Algae, Indian Agricultural Research \\ Institute (IARI), New Delhi-110012, India \\ (phone: +91-011-25848431; fax : +91-011-25741648) \\ e-mail: radhapr@gmail.com \\ (Received $3^{\text {rd }}$ May 2006; accepted $5^{\text {th }}$ July 2007)
}

\begin{abstract}
The influence of soil $\mathrm{pH}$ was evaluated on the abundance and generic diversity of cyanobacteria in soil samples collected from diverse rice soil ecologies of India. Qualitative and quantitative studies of the 52 soil samples collected from nine agroecologies was carried out using enrichment, MPN (Most Probable Number) techniques and diversity indices were measured. A total of 166 forms, including 130 heterocystous and 36 non-heterocystous isolates were isolated and the highest percentage of abundance of heterocystous forms was observed at $\mathrm{pH}$ of 8.1. Highest Shannon's diversity index was recorded at a $\mathrm{pH}$ of 6.9 , followed by $\mathrm{pH}$ of 7.4, while indices of richness and evenness ( $\mathrm{J}$ and E) were highest in soil samples of $\mathrm{pH}$ of 9.3. This study highlighted the successful colonization of cyanobacteria in rice field soils of diverse $\mathrm{pH}$ and the need for enrichment of the native flora as a means of exploiting the full potential of cyanobacterial biofertilizers in agriculture
\end{abstract}

Keywords: abundance; cyanobacteria; diversity indices; rice ecologies; soil $\mathrm{pH}$

\section{Introduction}

Cyanobacteria represent cosmopolitan prokaryotes, which can be found in almost every conceivable habitat, including soil, on rocks, in fresh water, and in salt water [6,11]. In aquatic environments, cyanobacteria often form thick microbial mats, serving as crucial components in such ecosystems, as they are the primary producers at the base of the microbial food web. Cyanobacteria also increase the oxygen concentration and improve other physico-chemical parameters of the environment, in which they grow and flourish [13]. They are also found in the deserts, where they remain dormant for most of the time, taking advantage of the occasional rains, although this is not the most common [7]. Because they secrete polysaccharides that bind soil, cyanobacteria help to control stability, erosion, runoff, and site availability for germination by higher plants. In nature, cyanobacteria are abundant in places where there is a major nitrogen-deficiency.

Among soil properties, $\mathrm{pH}$ is a very important factor in growth, establishment and diversity of cyanobacteria, which have generally been reported to prefer neutral to slightly alkaline $\mathrm{pH}$ for optimum growth $[23,10]$. Acidic soils are therefore one of the stressed environments for these organisms and they are normally absent at $\mathrm{pH}$ values below 4 or 5; eukaryotic algae, however, flourish under these conditions. Soil $\mathrm{pH}$ is also known to have a selective effect on the indigenous algal flora, especially cyanobacteria and their succession and abundance in soil. Species of Nostoc, Anabaena, Tolypothrix, Aulosira, Cylindrospermum, Scytonema, Westiellopsis and several other genera are widespread in Indian rice field soils and are known to contribute significantly to their fertility [29,9'15]. There are very few reports on the existence of cyanobacteria at low $\mathrm{pH}$ (acidic range) as they are in general, intolerant to low $\mathrm{pH}$ conditions $[1,8,5]$ 
Among the diverse habitats, rice fields constitute one of the favourable ecologies for the growth and proliferation of cyanobacteria [30,26,14]. In the 1970s, algalization or the enrichment of soil via inoculation of selected cyanobacterial strains led to the promotion of these biofertilisers among the farming community in South East Asia [26,28]. However, in recent years, an urgent need has felt to address inherent deficiencies, which have limited their extensive exploitation in diverse rice ecologies and soil types. In a country such as India, rice is grown under diverse ecologies with

Therefore, this investigation was aimed at quantification of the cyanobacterial diversity - in terms of population counts, relative generic abundance, and their correlation with $\mathrm{pH}$ of the various soil samples collected and isolation of dominant genera from diverse rice ecologies of India.

\section{Materials and methods}

\section{Collection of soil samples and isolation and enumeration of cyanobacteria}

Soil samples collected from diverse agroecological regions and soil types (Fig. 1 and Table 1) were measured for their EC and $\mathrm{pH}$ range and utilized for enrichment studies in BG -11 medium with/ without nitrogen supplementation. Enumeration of populations was carried out by MPN (Most Probable Number) technique and tabulated for each site under the various locations. The enrichment flasks and MPN tubes were regularly monitored for growth and observed microscopically. Standard plating / streaking techniques were used for isolation and purification of cyanobacterial strains [24].

\section{Identification and purification of cyanobacteria}

The growth pattern and morphological examination of the cyanobacterial strains was carried out at different stages of growth in nitrogen-free liquid and solid (agar) BG-11 medium. The strains were viewed under a Nikon (Microphot-FX) microscope and the nature of filaments and the shape and size of vegetative cells, heterocysts and akinetes, were analysed and assigned to different genera , using the keys of Desikachary [4].

\section{Measurement of soil $\mathrm{EC}$ and $\mathrm{pH}$}

The soil samples (soil : water $=1: 2.5$ ) were analysed with respect to their EC (Electrical Conductivity) and $\mathrm{pH}$ range following the methodology outlined by Black [2].

\section{Measurement of acetylene reducing activity}

Gas chromatographic quantification of ethylene formed (acetylene reduction activity, ARA) was utilized as an index of nitrogen fixation. The vials with log phase cultures (14d) were injected with acetylene (10\% gas phase) after removing an equal amount of air, using airtight syringes and incubated for 90 minutes under optimal conditions of temperature and illumination [18]. The samples $(1 \mathrm{ml})$ were injected into a Gas Chromatograph (Chemito, model GC 1000), fitted with an oven containing a $2 \mathrm{~m}$ long column of stainless steel ( $2 \mathrm{~mm}$ internal diameter) packed with Poropak N (80-100 mesh). Nitrogen gas flowing at the rate of $35 \mathrm{ml} \mathrm{min}^{-1}$ was used as the carrier, while hydrogen and air were used to produce the flame in the Flame Ionisation Detector. The oven, injector and detector were maintained at $100-120^{\circ} \mathrm{C}$ to allow for ionization and detection of ethylene produced. 
Commercially available standard ethylene was utilized for quantification and vials with an equivalent volume of water served as controls [18]. The ARA values were expressed per mg chlorophyll. Spectrophotometric estimation of the chlorophyll content of cells was carried out following the method of Mackinney [12]. All values presented are means of triplicate measurements.

\section{Statistical analyses}

The diversity indices (Shannon's diversity index and Simpson's index of diversity) were calculated using the standard formulae.

Correlation coefficients were calculated using Microsoft Excel package and analysed for their significance using Pearson's tables

\section{Results and discussion}

The trophic independence from carbon and nitrogen, together with a great adaptability to environmental variations, enables cyanobacteria to be ubiquitous. Their structural-functional flexibility provides them with not only great versatility, but also makes them among the most successful in extreme environments including high temperatures, high levels of UV light, and high salinity and inhabit a wide range of environments and niches. Their role in the soil ecosystem is manifold, the most important consequences being the fixation of nitrogen and carbon, besides promoting release of nutrients and reducing the rate of loss of water and soil through erosion. In paddy fields, their relative occurrence varies within large limits, ranging from 0 to 76$85 \%$. However, contrary to the general belief, nitrogen fixing forms are not invariably present in tropical rice soils. All India survey showed that out of 2,213 soil samples from rice fields, only about 33\% harboured nitrogen-fixing forms [27], and limited systematic analyses on their limited distribution has been undertaken in relation to major environmental factors [19,21,22].

Among the soil properties, $\mathrm{pH}$ is certainly the most important factor determining the flora and fauna composition. In culture media, the optimal $\mathrm{pH}$ for the growth of cyanobacteria ranges from $7.5-10$, with a lower limit of $6.5-7.0$. However, in soilculture experiments, soils having slightly alkaline reaction were more favourable, while in natural environments cyanobacteria prefer neutral to alkaline $\mathrm{pH}[3,20]$. The development of soil acidity is generally believed to be associated with the base unsaturation caused by leaching out of bases and genesis from base-poor acidic rocks. The dissolved or free acidic substances, such as sulphuric acid and ferric and aluminium sulphate, accentuate acidity in acid sulphate soils [5].

In the present investigation, soil samples were collected from nine locations (Fig.1), differing in their $\mathrm{EC}$ and $\mathrm{pH}$ values and evaluated for cyanobacterial abundance and generic diversity. A total of 166 forms, including 130 heterocystous and 36 heterocystous isolates were recorded. A predominance of heterocystous forms (68 95\%) was observed at all locations, while non-heterocystous forms exhibited 5-32\% abundance in the various locations (Table 1). Highest \% abundance of heterocystous forms was observed at $\mathrm{pH}$ of 8.1 , followed by 7.9 (83 and $80 \%$ respectively). In terms of non-heterocystous forms, soil samples with $\mathrm{pH}$ of 7.4 and 9.3 recorded highest $\%$ abundance. 


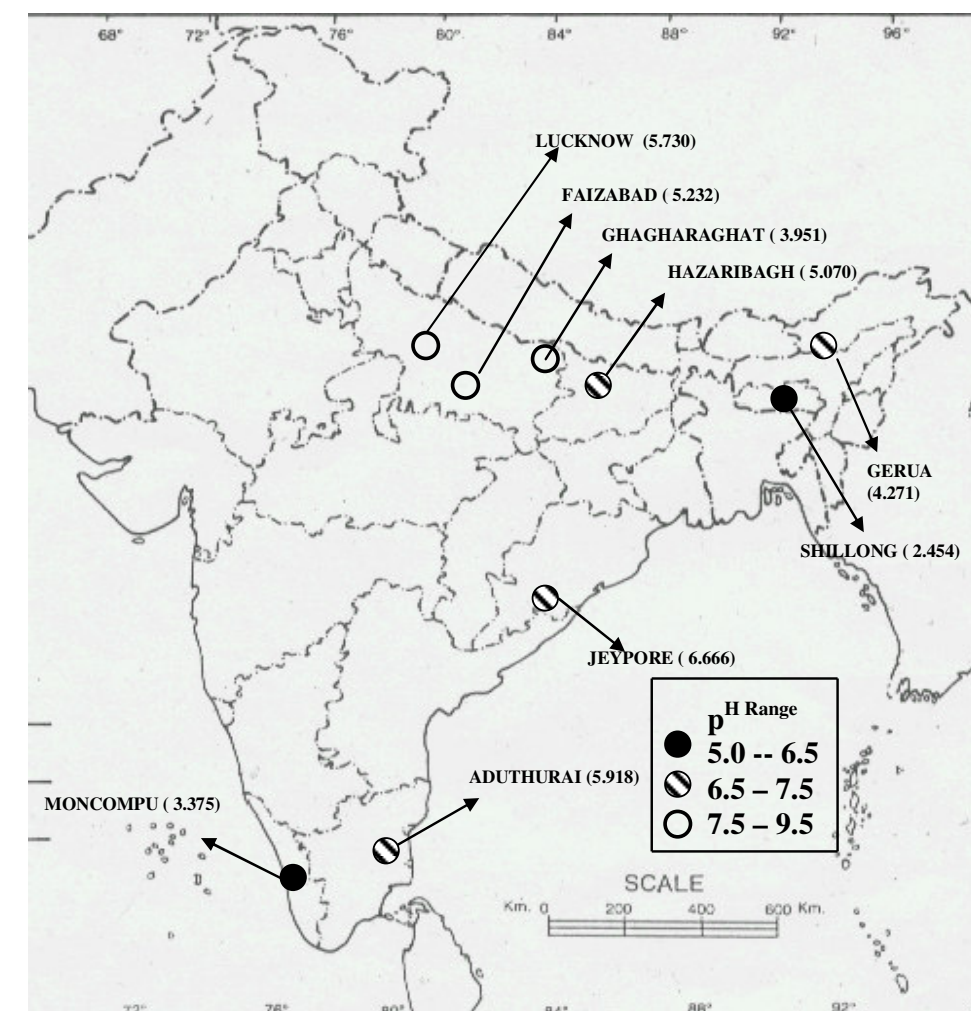

Figure 1. Map of India depicting the various locations sampled, along with their pH range and Simpson's Reciprocal diversity indices (given in parentheses)

Table 1. Occurrence and distribution of cyanobacteria in various locations in India, along with selected diversity indices

\begin{tabular}{cccccccc}
\hline Locations & $\begin{array}{c}\text { EC } \\
(\mathbf{d S} / \mathbf{m})\end{array}$ & $\begin{array}{c}\text { Total } \\
\text { no of } \\
\text { Genera }\end{array}$ & $\begin{array}{c}\text { Noterocystous } \\
\text { forms }\end{array}$ & $\begin{array}{c}\text { Heterocystous } \\
\text { forms }\end{array}$ & $\begin{array}{c}\text { Shannon } \\
\text { H }\end{array}$ & J & E \\
\hline $\begin{array}{c}\text { Aduthurai } \\
\text { (Tamil }\end{array}$ & 3.4 & 19 & $6(32 \%)$ & $13(68 \%)$ & 1.909 & 0.918 & 0.843 \\
$\begin{array}{c}\text { Nadu) } \\
\text { Jeypore }\end{array}$ & 2.7 & 20 & $5(25 \%)$ & $15(75 \%)$ & 2.038 & 0.927 & 0.853 \\
$\begin{array}{c}\text { (Orissa) } \\
\text { Hazaribagh } \\
\text { (Bihar) }\end{array}$ & 2.9 & 17 & $4(23 \%)$ & $13(77 \%)$ & 1.785 & 0.903 & 0.828 \\
$\begin{array}{c}\text { Lucknow } \\
\text { (Uttar }\end{array}$ & 4.4 & 19 & $5(26 \%)$ & $14(74 \%)$ & 1.836 & 0.943 & 0.896 \\
$\begin{array}{c}\text { Pradesh) } \\
\text { Faizabad } \\
\text { (Uttar }\end{array}$ & 3.5 & 15 & $3(20 \%)$ & $12(80 \%)$ & 1.859 & 0.894 & 0.802 \\
$\begin{array}{c}\text { Pradesh) } \\
\text { Ghagraghat } \\
\text { (Uttar }\end{array}$ & 2.9 & 18 & $3(17 \%)$ & $15(83 \%)$ & 1.541 & 0.860 & 0.778 \\
$\begin{array}{c}\text { Pradesh) } \\
\text { Gerua } \\
\text { (Assam) }\end{array}$ & 2.9 & 31 & $7(23 \%)$ & $24(77 \%)$ & 1.691 & 0.813 & 0.678 \\
$\begin{array}{c}\text { Shillong } \\
\text { (Meghalaya) }\end{array}$ & 2.5 & 09 & $1(5 \%)$ & $8(95 \%)$ & 0.964 & 0.878 & 0.874 \\
$\begin{array}{c}\text { Moncompu } \\
\text { (Kerala) }\end{array}$ & 4.2 & 18 & $2(11 \%)$ & $1(89 \%)$ & 1.442 & 0.804 & 0.704 \\
\hline
\end{tabular}


Simpson's Reciprocal indices (Fig.1) were highest in Jeypore soil samples, followed by those from Aduthurai. Shannon's diversity index was highest at a $\mathrm{pH}$ of 6.9, followed by $\mathrm{pH}$ of 7.4, indicative of the higher number of genera recorded in these soil samples. Indices of richness and evenness ( $\mathrm{J}$ and $\mathrm{E}$ ) were highest in soil samples of $\mathrm{pH}$ of 9.3 (Table 2). Shannon's indices are strongly biased towards richness, as it is calculated from proportional abundances of the species. On the other hand, Simpson's index is a measure of diversity, which takes into account both richness and evenness, although it gives more weight to the more abundant species in a sample.

Table 2. Major genera and their relative abundance in the samples

\begin{tabular}{ccc}
\hline Genus & Total number of strains & Relative abundance \\
\hline Anabaena & 46 & $100 \%$ \\
Nostoc & 51 & $100 \%$ \\
Calothrix & 14 & $89 \%$ \\
Scytonema & 3 & $22 \%$ \\
Westiellopsis & 3 & $22 \%$ \\
Hapalosiphon & 8 & $89 \%$ \\
Aulosira & 1 & $11 \%$ \\
Cylindrospermum & 5 & $56 \%$ \\
Oscillatoria & 9 & $78 \%$ \\
Phormidium & 20 & $89 \%$ \\
Lyngbya & 1 & $11 \%$ \\
Aphanocapsa & 5 & $22 \%$ \\
\hline
\end{tabular}

The extensive diversity in $\mathrm{pH}$ and EC led to a significant effect on the abundance of cyanobacterial species, depicted as log values of MPN (Fig. 2 and 3).

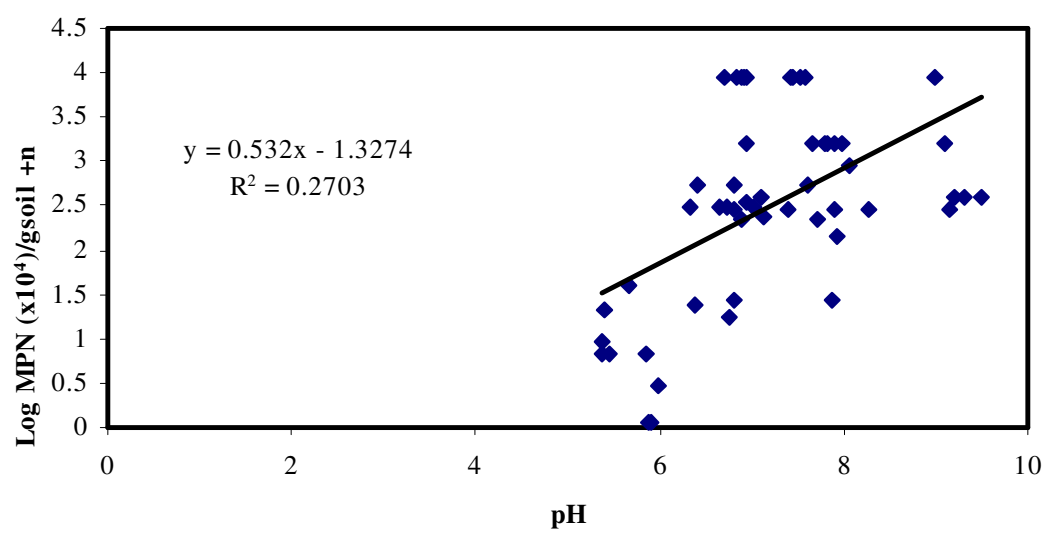

Figure 2. Abundance of cyanobacterial populations ( $\log M P N / g$ soil) as a function of $p H$

$$
(r=0.52 ; P<0.01)
$$




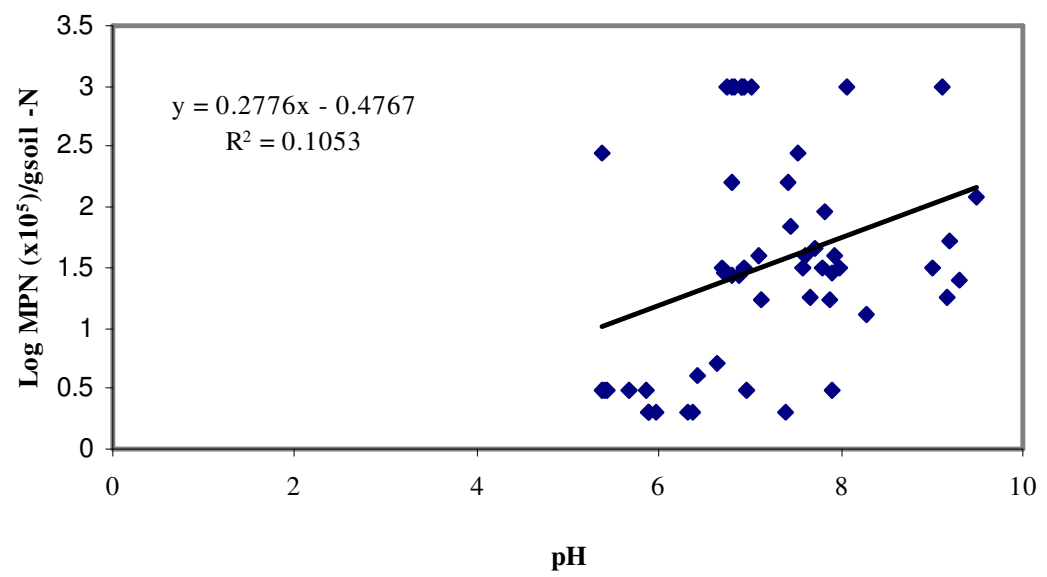

Figure 3. Abundance of cyanobacterial populations ( $\log M P N / g$ soil) as a function of EC

$$
(r=0.32 ; P<0.01)
$$

The $\mathrm{pH}$ values and to a lesser extent $\mathrm{EC}$ of the various locations showed a significant positive correlation with MPN (expressed as log values), especially in relation to the enrichment studies in nitrogen supplemented media. The correlation between EC and $\mathrm{pH}$ was observed to be positive, but Pearson's coefficient was not significant (Fig.4).

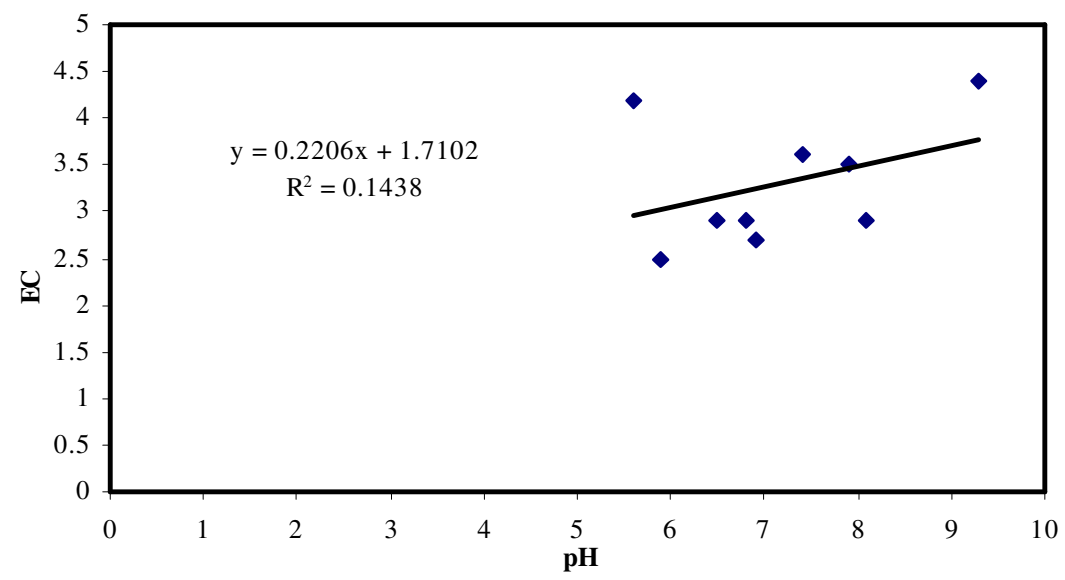

Figure 4. Correlation between $\mathrm{EC}$ and $\mathrm{pH}$ (average over all locations; $r=0.38$, not significant)

Cyanobacteria belonging to 12 genera were isolated which included 8 heterocystous forms: Anabaena, Nostoc, Westiellopsis, Calothrix, Scytonema, Aulosira, Hapalosiphon, Cylindrospermum and 4 non-heterocystous forms: Phormidium, Oscillatoria, Lyngbya and Aphanocapsa. The genera-wise distribution of the five dominant cyanobacterial forms at various pH levels is illustrated in Figure 5. 


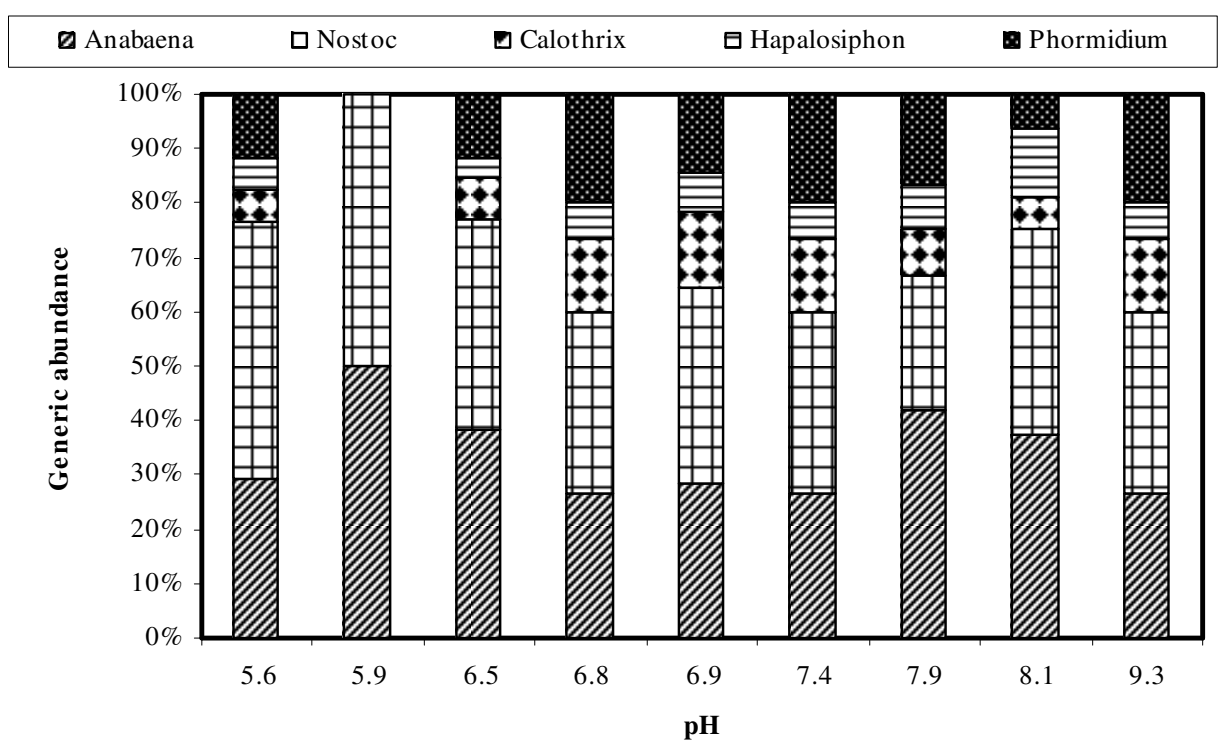

Figure 5. Distribution of the selected dominant genera as a function of soil pH.

In general, Nostoc and Anabaena recorded maximum number of isolates i.e. 10 at $\mathrm{pH}$ of 6.5. The number of isolates belonging to the genera Anabaena and Nostoc also showed the highest relative abundance of $100 \%$, while lowest values were recorded for Aulosira and Lyngbya, as they were isolated only from one of the 9 locations. The relative abundance of cyanobacteria in rice soils and biofertilizer inocula from four countries revealed that significant correlation could be made with respect to $\mathrm{pH}$ and available $\mathrm{P}$ content of soils [21]. Algalization, when effective, is generally associated with increase in yield but the success of algalization is dependent on a number of factors that include flooding due to rains, simultaneous use of inorganic fertilizers, animal manures, pesticides and amount of light available to the cyanobacteria as the plant grows.

Earlier studies on the distribution pattern of cyanobacteria in soils of Andhra Pradesh, Haryana, Delhi, Rajasthan, Uttar Pradesh and Punjab revealed that although recurrent combination of forms were discernable, there appeared to be a localized distribution of cyanobacteria depending upon the soil $\mathrm{pH}$, electrical conductivity and exchangeable sodium. Species of Nostoc, Calothrix, Scytonema, Hapalosiphon and Wetiellopsis were recorded in salt-affected soils of Maharashtra and Andhra Pradesh (where $\mathrm{pH}$ of the soil varied from 6.0 to 9.0), although the species of Nostoc and Calothrix were predominant. On analyzing the total cyanobacterial flora, it was observed that out of the total 37 species, 50 percent were nitrogen- fixing strains, including the non-heterocystous nitrogen fixers. Unicellular and colonial forms, with extensive mucilage like Aphanocapsa, Aphanothece, Chroococcus, Gloeocapsa and Gloeothece and filamentous species of Scytonema, Lyngbya and Tolypothri were also very common in Maharashtara soils. A significant reduction in soil salinity (12-35\%) due to repeated cultivation of Anabaena torulosa in soils rendered saline owing to bad farm management has also been reported Cyanobacteria have been found not only to grow in highly saline-alkali soils, but also improve the physico-chemical properties of the soil by enriching them with carbon, nitrogen and available phosphorus $[9,10]$. Successive cultivation of BGA makes the environment more favourable and after a few 
years it may help to produce a reasonably good yield of crops, as observed by Singh [23] for sugarcane after 3 years of reclamation with BGA. Although infrequent at $\mathrm{pH}$ below 6.0, their ability to grow in diverse $\mathrm{pH}$ ranges and modify their environment makes them successful in any niche. Acidic soils, in general do not support their growth, although a few reports on their presence in soils with $\mathrm{pH}$ values between 5 and 6 are available $[1,16,17]$.

Correlation between the number of isolates from each of the dominant genera and $\mathrm{pH}$ of the location sampled also showed a positive correlation for Calothrix, Phormidium and Hapalosiphon (Fig. 6). The numbers of isolates belonging to the genera Nostoc and Anabaena, however, exhibited a negative correlation, indicating that although these two genera show highest relative abundance quantitatively, their relative tolerance to $\mathrm{pH}$ is low. Nostoc and Anabaena, therefore, exhibited superior establishing and adaptive traits, although in terms of numbers, they showed an uneven distribution at different $\mathrm{pH}$. However, the correlation was not statistically significant in any of these cases. Among the non-heterocystous cyanobacteria, Phormidium was the most cosmopolitan -20 isolates as against 9 and 5 belonging to Oscillatoria/Lyngbya. A similar trend was observed on correlating EC values and number of isolates belonging to the dominant genera (data not shown). Species of Calothrix and Aulosira have been reported to be ubiquitous in rice fields of Kerala where $\mathrm{pH}$ ranges from $3.5-6.5$ [1]. Also, the number of spore producers is known to show a positive correlation with soil $\mathrm{pH}$. Enrichment of such soils with the indigenous cyanobacterial isolates may help in ameliorating the land and making them suitable for obtaining higher yields as benefits, other than nitrogen fixation, include solubilisation of phosphorus, improved soil structure and synthesis of growth promoting substances are also known.

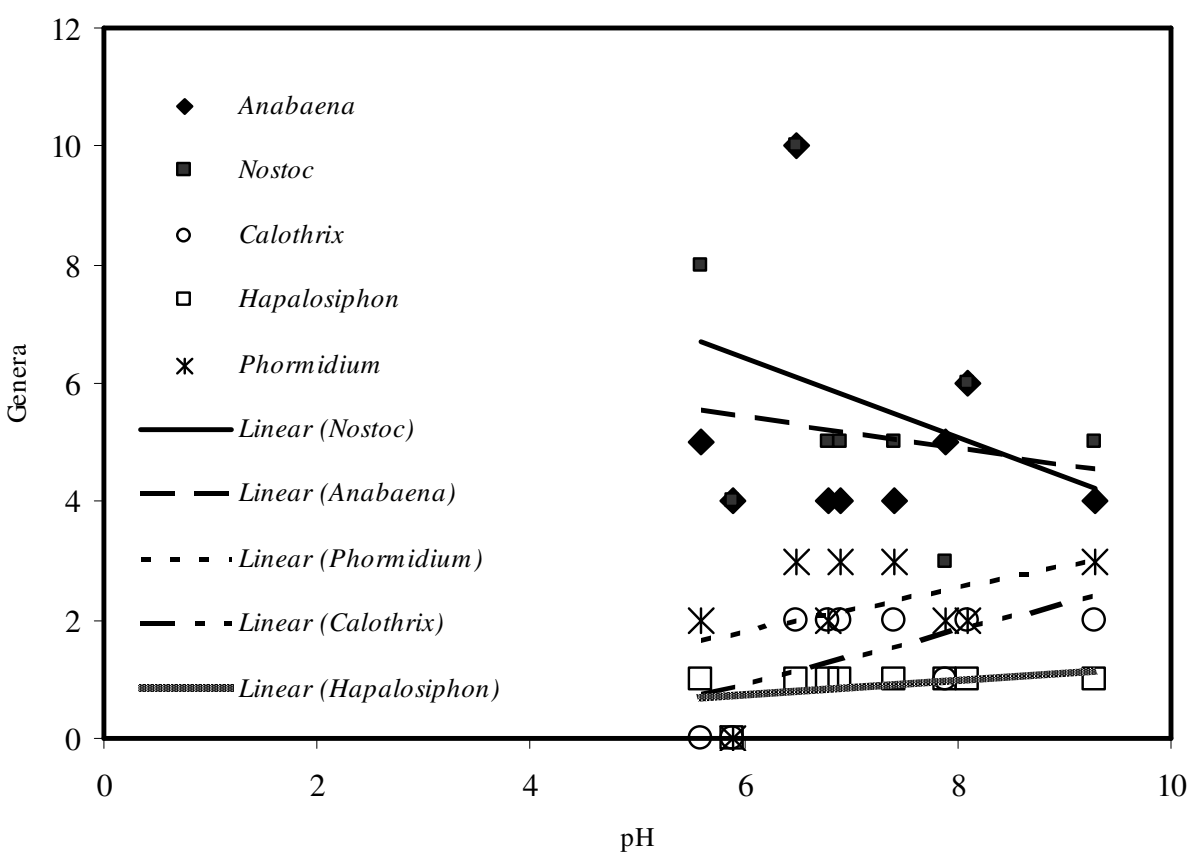

Figure 6. Correlation of number of isolates of dominant genera with soil $\mathrm{pH}$.

The diversity within a genus was also further analysed by measuring the nitrogen fixing potential (using acetylene reducing activity as an index) of 46 isolates of 
Anabaena (Fig.7). Highest values were recorded in the isolates from Assam (A43 and 44), followed by the isolate from saline-alkali soil samples from Lucknow (A15).

The effect of $\mathrm{pH}$ on algal flora is generally difficult to evaluate as it is often correlated with other factors, for $e . g$. arid soils are almost universally alkaline and many continuously wet soils acidic. Among correlations between the relative abundance of the individual groups of heterocystous cyanobacteria and soil physico-chemical properties, only the correlation between $\mathrm{pH}$ and the relative abundance of Nostoc was found to be statistically significant, but a degree of bias was introduced when dry and wet samples were tested separately [21]. Contradictory reports regarding the occurrence in acid and very acid environments are available. However, one of the most acid lakes ( $\mathrm{pH}$ 2.9) was observed to be inhabited by Oscillatoria/Limnothrix and Spirulina [25]. Despite the preference for neutral-highly alkaline environments, acidic soils do exhibit low diversity and abundance of cyanobacteria [11].

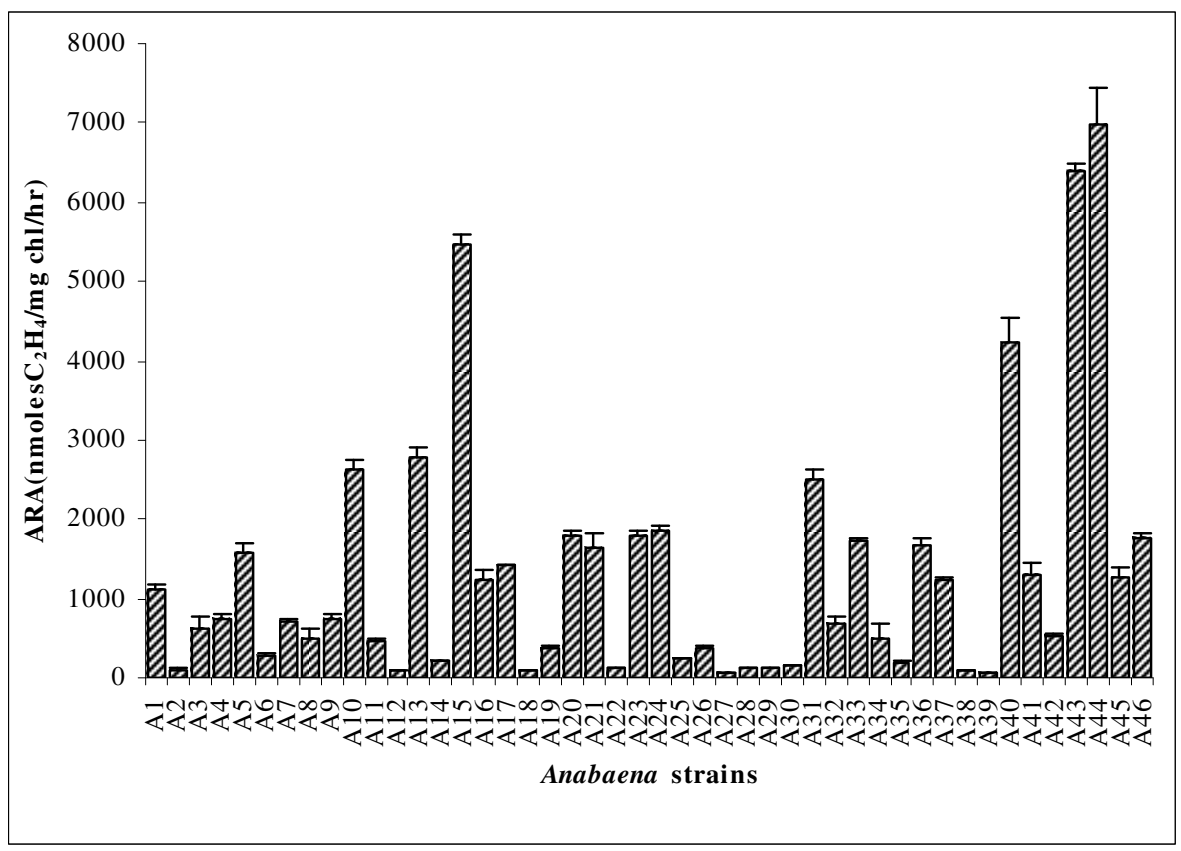

Figure 7. Diversity in nitrogen fixing potential (measured as acetylene reducing activity,

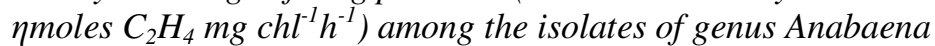

Therefore, efforts need to be focused towards enrichment of indigenous cyanobacterial populations, which are better adapted to the specific niche, through development of multiple inocula preparations on a regional basis. Research programs should be oriented towards agricultural practices, including application of biofertilizers, which enhance the growth and proliferation of indigenous strains.

Acknowledgements. The authors are grateful to the Indian Council of Agricultural Research, New Delhi for the AP Cess Fund project (F.No. 13(37)/2002-SW\&DF) for providing financial assistance. The facilities required for carrying out this investigation provided by the Centre for Conservation and Utilization of Blue Green Algae, IARI, New Delhi is gratefully acknowledged. The authors thank Dr. K.V. Bhat, Senior Scientist, NBPGR, New Delhi, for assistance in statistical analyses. 


\section{REFERENCES}

[1] Aiyer, R .S. (1965): Comparative algological studies in rice fields in Kerala state. Agricultural Research Journal of Kerala 3(1): 100-104.

[2] Black, C.A. (1992): Methods of soil analysis Part 1. - American society of Agronomy, USA .

[3] De, P.K. (1939): The role of blue-green algae in nitrogen fixation in rice fields. Proceedings of the Royal Society of London Series B 127: 121-139.

[4] Desikachary, T.V. (1959): Cyanophyta - Indian Council of Agricultural Research, New Delhi.

[5] Dominic, T.K, .Madhusoodanan, P.V. (1999): Cyanobacteria from extreme acidic environments. - Current Science 77(8): 1021-1022.

[6] Hoffmann, L. (1989): Algae of terrestrial habitats. - The Botanical Review 55: 77-105.

[7] Hu, C., Zhang, D. Huang, Z., Liu, Y. (2003): The vertical microdistribution of cyanobacteria and green algae within desert crusts and the development of the algal crusts - Plant Soil 257: 97-111.

[8] Hunt, M.E., Floyd, G.L. Stout, B.B. (1979): Soil algae in field and forest environments. Ecology 60(2): 362-375.

[9] Kaushik, B.D. (1991): Cyanobacterial response of crops in saline irrigated with saline ground water. - In: Shastree, N.K (ed.) Current Trends in Limnology, Vol. 1. Narendra Publishing House, New Delhi.

[10] Kaushik, B.D. (1994): Algalization of rice in salt-affected soils. - Annales of Agricultural Research 14: 105-106.

[11] Kulasooriya, S.A. (1998). Cyanobacteria and Azolla as biofertilizer for rice. - In: Subramanian, G.S., Kaushik, B.D. and. Venkataraman, G.S (eds) Cyanobacterial Biotechnology, New Delhi: Oxford \& IBH Publishing Co. Pvt. Ltd.

[12] MacKinney, G. (1941): Absorption of light by chlorophyll solutions. - Journal of Biological Chemistry 140: 315-322.

[13] Mandal, B., Vlek, P.L.G., Mandal. L.N. (1998): Beneficial effect of blue green algae and Azolla excluding supplying nitrogen, on wetland rice fields: a review. - Biology and Fertility of Soils 27: 329-342.

[14] Nayak, S., Prasanna, R., Dominic, T.K., Singh, P.K. (2001): Floristic abundance and relative distribution of different cyanobacterial genera in rice field soil at different crop growth stages. - Phykos 40: 14 -21.

[15] Nayak, S., Prasanna, R., Dominic, T.K., Singh, P.K. (2004): Effect of BGA- Azolla biofertilizers on nitrogen fixation and chlorophyll accumulation at different depths in soil cores. - Biology and Fertility of Soils 40: 67-72.

[16] Okuda, A., Yamaguchi, M. (1956): Nitrogen fixing microorganisms in paddy soils II. Distribution of blue green algae in paddy soils and the relationship between the growth of them and soil properties. - Soil and Plant Food 2: 4-7.

[17] Prasad, B.N., Mehrotra, R.K., Singh, Y. (1978): On pH tolerance of some soil blue green algae - Acta Botanica Indica 6(2): 130-138.

[18] Prasanna, R., Tripathi, U., Dominic, T.K., Singh, A.K., Yadav, A.K., Singh, P.K. (2003): An improvised technique for measurement of nitrogen fixation by blue green algae and Azolla using intact soil cores. - Experimental Agriculture. 39: 145-150.

[19] Roger, P.A. (1996.): Biology and management of the floodwater ecosystem in rice fields. - IRRI, Manila.

[20] Roger, P.A., Reynaud, P.A. (1979): Ecology of blue green algae in paddy fields - In: International Rice Res. Institute, Los Banos, Philippines,

[21] Roger, P.A., Santiago-Ardales, S., Reddy, P.M., Watanabe, I. (1987): The abundance of heterocystous blue-green algae in rice soils and inocula used for application in rice fields. - Biology and Fertility of Soils 5: 98-105.

[22] Singh, P.K., Bisoyi, R.N. (1989): Blue green algae in rice fields. - Phykos 28: 181-195. 
[23] Singh, R.N. (1961): Role of blue-green algae in nitrogen economy of Indian agriculture. Indian Council of Agricultural Research, New Delhi.

[24] Stanier, R.Y., Kunisawa R., Mandel, M., Cohen-Bazire, G. (1971): Purification and properties of unicellular blue-green algae (order Chroococcales). - Bacteriological Reviews 35: 171-205.

[25] Steinberg, C.E.W., Schafer, H., Beisker W. (1997): Do acid-tolerant cyanobacteria exist? - Acta Hydrochimica Hydrobiologica 26 (1): 13-19.

[26] Vaishampayan, A., Sinha, R.P., Hader, D.P., Dey, T., Gupta, A.K., Bhan, U., Rao, A.L. (2001): Cyanobacterial biofertilizers in rice agriculture. - Botanical Reviews 6: 453-516.

[27] Venkataraman, G.S. (1975): The role of blue green algae in tropical rice cultivation. - In: Stewart, W.D.P. (ed.) Nitrogen fixation by free-living microorganisms. Cambridge University Press, London, pp.207-268.

[28] Venkataraman, G.S. (1979): Algal inoculation of rice fields. - In: Nitrogen and Rice, International Rice Res. Institute, Los Banos, Philippines, pp.311-321.

[29] Venkataraman, G.S. (1981): Blue-green algae for rice production - a manual for its promotion. - FAO Soils bulletin no. 46. FAO, Rome.

[30] Whitton, B.A. (2000): Soils and rice fields. - In: Whitton, B.A., Potts, M. (eds.): The Ecology of Cyanobacteria, Kluwer Academic Publishers, Dordrecht, pp. 233-255. 